\title{
Merian's metamorphoses
}

Nurtured from an early age in the art of still-life painting and naturalistic illustration, the courageous seventeenthcentury artist Maria Sibylla Merian allied her vision and her skills to convey the complex life-cycles of insects.

\section{Martin Kemp}

ए or a 52-year-old painter who specialized in illustrating plants and insects to make a self-financed voyage to Surinam in 1699 to document the metamorphosis of exotic butterflies and moths is remarkable enough. For a woman, accompanied only by her 21-year-old daughter, it represents one of the most heroic acts in the history of the natural sciences. Maria Sibylla Merian of Frankfurt was an extraordinary person. She was also responsible for forging a new vision of how the life-cycles of insects could be brought before our eyes.

Her 'ecological' presentation, which she pioneered in The Wondrous Transformation of Caterpillars and their Remarkable Diet of Flowers in 1679 and 1683, found its finest expression in her Metamorphosis of the Insects of Surinam in 1714. The eggs, larvae, chrysalises and mature insects are portrayed in living communion with the plant on which their "worms" feed.

In her depiction of the moth Arsenura armida on the "Palisade tree" — so called because it provides the thick poles from which "the huts in America are built" - the stages in the life-cycle are interwoven with the plant in a living tapestry. As she explains: "Each year this kind of caterpillar comes three times to this tree; it is yellow with black stripes and decorated with six black spines. When they have reached a third of their final size they shed their skin and become orangeyellow with black spots on their limbs .... Several days later they shed their skin once more; on 14 April 1700 they turned into chrysalises; on 12 June moths like those emerged. The lower and smaller is the male; the larger and the upper one the female."

\section{Her aim was not systematic classification, anatomical description or priority in academic disputes, but to conduct us on a visual journey through the wonders of transformation.}

How was this vision conceived, when it is so different from the taxonomic 'portraits' of organisms found in the standard books? It can be seen as an extension of the kind of art in which she was steeped. Still-life painting and naturalistic illustration were in her blood.

She was the daughter of Matthias Merian the Elder, an engraver, illustrator and publisher, and her stepfather was the still-life painter Jacob Marrell. She married the painter Johann Andreas Graff. The kinds of still lifes that she learnt to paint with much skill were replete with descriptive detail and

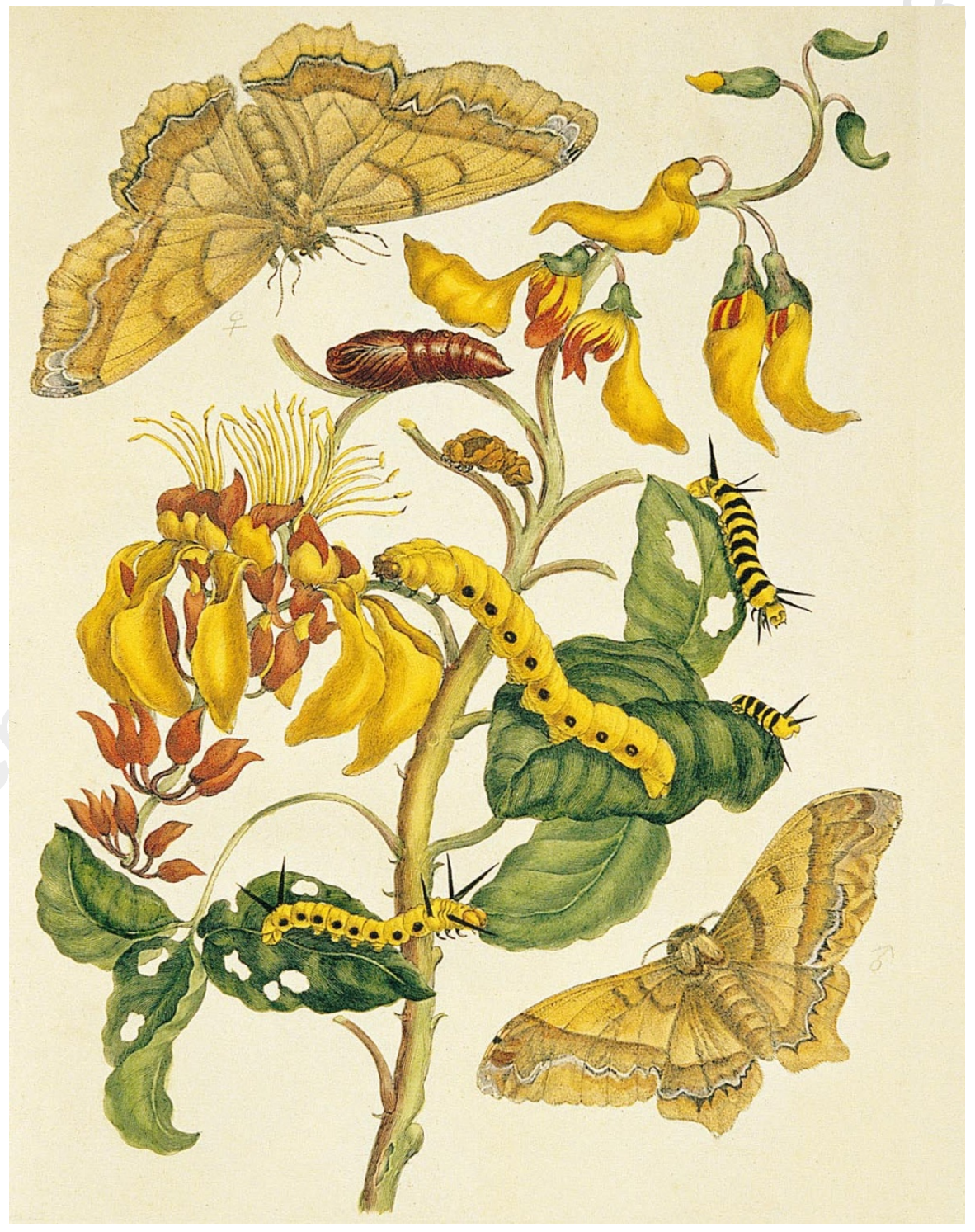

Maria Sibylla Merian's "Palisade tree" (Erythrina fusca) with the moth Arsenura armida, from De Metamorphosibus insectorum Surinamensium, 1714.

composed with decorative intent, but they also frequently embodied implicit narratives that remind us of the passing glories of earthly beauty. Maggots create decay at the heart of luscious fruit; leaves are holed by caterpillars; and gorgeous butterflies flutter through their transitory existence.

Should we wonder whether this 'vanitas' motif was relevant to natural history, we need only cite the title of the publication devoted to the mayfly by the microscopist and entomologist Jan Swammerdam, A Figure of Man's Miserable Life (1675). Merian is not so explicit, and the beauty of her observations and vivid depictions are sufficient unto themselves. But, as a pious believer, she knew that she was working for an audience who would place her world of transformation in the proper theological context. She would have known that description, decoration and divine message were inseparably conjoined within a temporal framework.

As she had written in the preface to her Transformations, "I moved to present God's miracles .... Thus do not seek to praise and honour me for this work, but rather God, glorifying him as the creator of even the smallest and most insignificant of these worms." $\square$ Martin Kemp is in the Department of the History of Art, University of Oxford, 35 Beaumont Street,

Oxford OX1 2PG, UK.

e-mail:martin.kemp@trinity.oxford.ac.uk 